\title{
57th Berlinale 2007
}

\author{
By Ron Holloway \\ Spring 2007 Issue of KINEMA
}

\section{EUROPEAN Film Market}

Now in his sixth year as director of the Berlin International Film Festival, Dieter Kosslick takes particular pride in changing the image of the festival each time around. This year, for the $57^{\text {th }}$ Berlinale (8-18 February 2007), he expanded the European Film Market (EFM) beyond the environs of the roomy Martin Gropius Bau, a short three-minute walk from festival headquarters on the Potsdamer Platz. "Last year, we offered buyers and sellers 5000 square metres of space in the Gropius Bau," he said in an interview, "but this year every nook and cranny of the building couldn't accommodate all of the market professionals who requested stands." So, to handle the overflow, the fifth floor of the Berlinale Service Center in the Debis atrium was reserved for latecomers. Altogether, more than 5000 market professionals were accredited for the Berlinale, while over 250 films from 51 countries were programmed in 1100 screenings.

Walk across the street from the Martin Gropius Bau to the Abgeordenetenhaus von Berlin (Berlin Parliament House), and you would find national delegates from the European Union gathered for roundtable sessions at the Berlinale Co-Production Market. Jump in a shuttle bus, and you could visit the Berlinale Talent Campus quartered in the nearby Hebbel am Ufer (HAU) complex. Next year, when renovations have been completed on the Haus der Kulturen der Welt (House of World Cultures) in Tiergarten Park, the Berlinale Talent Campus will move back to its natural habitat. The Campus is one of the Berlinale's success stories. Its strategy of providing a creative platform for film students, by exposing them to lectures and workshops by professionals visiting the festival, has already been effectively exported to India, where it prospers as an integral part of the Cinefan festival in New Delhi.

\section{Innovations}

A key festival innovation this year was the change in the name and scope of the traditional Children and Youth Film Festival. Now titled "Generation," the section couples the former "Kinderfilmfest" (Children's Film Festival) with the newly established "14plus" (Youth Film Program). As far back as 1978, the Berlinale had been awarding prizes to entries in the Children's Film Festival. Then, in 2004, the growth of the festival section required a separate competition for the secondary 14plus Youth Film Program. Renamed as "Kplus" and "14plus," the section welcomed an estimated audience of over 40,000 to four spacious venues scattered across the city.

A second innovation was prompted by the Eckart Witzigmann Prize, awarded to Dieter Kosslick by the German Academy for Culinary Studies. Kosslick responded to this personal honour by launching a new festival section titled "Celebrating Culinary Cinema - Eat, Drink, See Movies" in the Kino venue of the Martin Gropius Bau. Among the series of ten films dealing with the culinary art were two new documentaries: Les Blank and Gina Lebrecht's documentary All in This Tea (USA) and Doris Dörrie's How to Cook Your Life (Germany). On the culinary side were on-the-spot menus by five of Berlin's top restaurant chefs.

Still another innovation was "Magnum in Motion" - a celebration of the $60^{\text {th }}$ anniversary of the founding of the legendary photographer agency. The festival screened 33 films by and about Magnum photographers in the Zeughauskino of the German Historical Museum. A dozen Magnum photographers and filmmakers showed for the anniversary event. In addition, there was an exhibition in the Camera Work gallery of Berlin photos taken by Magnum photographers between 1946 and 2006. Alone the Magnum photos taken of Marilyn Monroe and Clark Gable by Eve Arnold during the 1960 filming of John Huston's The Misfits were a cineastic attraction.

\section{The Winners and the Losers}

Wang Quan'an's fiction-documentary Tu ya de hun shi (Tuya's Marriage, China) was awarded the Golden Bear, in addition to an award from the Ecumenical Jury. Set in rural Mongolia, Tuya's Marriage mirrors the plight of nomadic shepherds whose way of life is threatened by government plans to move them to urban shelters. When Tuya is requested by her invalid husband to divorce him and marry another, she reluctantly 
views this as a possibility to care for the man she loves, feed their children, and remain on the steppes. The decision only hastens the breakdown of the family.

For the third time in a row, the Silver Bear for Best Actress was awarded to a German thespian: Nina Hoss in Christian Petzold's Yella follows Sandra Hüller in Hans-Christian Schmid's Requiem (2006) and Julia Jentsch in Marc Rothemund's Sophie Scholl - Die letzten Tage (Sophie Scholl - The Last Days, 2005). As refined as her performance is, much of the credit for her cool, icy, distant performance as an accomplice in ruthless venture capital schemes belongs to her director. This is the third time Christian Petzold has starred Nina Hoss in his psycho-thrillers, after Toter Mann (Dead Man, 2001) and Wolfsburg (2002). Yella, shot in Hanover and Wittenberge on the Elbe, scores as the best German film of the current season.

Overlooked for a Berlinale Bear, Stefan Ruzowitzky's Die Fälscher (The Counterfeiters, Germany-Austria) stars Karl Markovics and August Diehl as an opposing pair of adept counterfeiters, one a thief with principles and the other a political idealist, in the Sachsenhausen prison camp during the last years of the Second World War. Based loosely on a true story about a Nazi plan to flood the money market with fake American dollars and British pounds in order to cripple the economies of the Allies, The Counterfeiters deserves praise as a psychological thriller offering an entirely different perspective to the Holocaust.

\section{Hollywood Highlights}

Some American films were critical hits at the Berlinale. Robert De Niro's The Good Shepherd, awarded the Silver Bear for Individual Artistic Contribution on the part of the ensemble cast, proposes to tell the behind-the-scenes story of the founding of the Central Intelligence Agency (CIA), one of the most powerful secret services in the world and particularly active during the Cold War years as adversary of the Soviet KGB. Scripted by Eric Roth (Robert Zemeckis's Forrest Gump, Steven Spielberg's Munich), the project reportedly went through several rewrite versions and directorial changes before reaching the Berlinale in its truncated version.

Two American films running out-of-competition might easily have contended as favourites for the Golden Bear: Clint Eastwood's Letters from Iwo Jima and Paul Schrader's The Walker. Letters from Iwo Jima, in contrast to Eastwood's Flags of Our Fathers, pays tribute to Japanese general Tadamichi Kuribayashi, an intellectual who was well acquainted with the United States through travels and thus managed to delay defeat by a month on this volcanic island, although at a horrendous cost of 20,000 Japanese lives. The Walker (USAUK), starring Woody Harrelson as a middle-aged gay version of Richard Gere's male prostitute in Schrader's American Gigolo (1979), sketches an intriguing portrait of haut-culture ambivalence at a Washington canasta club frequented by aristocratic ladies of the past and present.

\section{Thespian Triumphs}

Acting performances were the icing on the Berlinale cake. Awarded the Grand Jury Prize, Ariel Rotter's El otro (The Other, Argentina-France-Germany) also merited Julio Chavez the Silver Bear for Best Actor. The story of a business man who assumes the identity of a dead man in order to get away from his own humdrum existence, the impersonator's journey into his inner self turns out in the end to be more than he can handle. Ivan Barney is a standout as the suave waiter and later savvy hotelier in Jiř́ Menzel's Obsluhoval jsem anglického krále (I Served the King of England, Czech Republic-Slovakia), another of the director's patented adaptations of Bohumil Hrabal novels, this one spanning Czech history from the 1930s up to the present. I Served the King of England was awarded a FIPRESCI Prize.

As a hand-sex artist in a London porno club in Sam Garbarski's Irina Palm (Belgium-Germany-LuxembourgUK-France), Marianne Faithfull gives an exceptionally nuanced performance that is both hilariously funny and warmly sympathetic, for the grandmother has accepted this lucrative job in order to pay for her grandson's medical bills. And Marion Cotillard's insightful interpretation of the personality of the legendary Edith Piaf is the primary reason why Olivier Dahan's La môme (La vie en rose, France-UK-Czech Republic) was given a standing ovation at the opening night gala.

\section{Awards for Directors}

The Silver Bear for Best Director went to Josef Cedar for Beaufort (Israel), the story of the last days of an 18-year occupation of Beaufort Fortress in Lebanon. The departure of Israeli troops in May of 2000 necessitated the destruction of the symbolic fort as the Israeli army retreated under fire. Cedar, who studied 
cinema at New York University and philosophy at Hebrew University in Jerusalem, crafted Beaufort more as a psychological drama than as a war film. Awarded the Peace Prize, Bille August's Goodbye Bafana (Germany-France-Belgium-UK-Italy-South Africa) reviews the prison years of Nelson Mandela on Robben Island during the apartheid years at the end of the 1960s, the story told through the eyes of an Afrikaner warder who spoke the language of the prisoners.

Unfortunately overlooked for an award, Saverio Costanzo's In memoria di me (In Memory of Myself, Italy) delves deep into the existential universe of the cloister in which every word and gesture takes on meaning in the light of faith and belief. We follow the path taken by a young novice (Christo Jivkov) from entrance into the monastery until his departure, the account more a personal journey than a study of the religious order itself. Costanzo apparently is fascinated by "border" conditions. His previous feature film Private (2004), set inside a Palestinian residence occupied by Israeli soldiers bent on driving the family out of their home, was awarded at the Locarno film festival.

\section{Forum in Top Form}

Several German-language entries in the International Forum of New Cinema confirmed that creative voices are increasingly evident in the cinemas of Germany, Austria, and Switzerland. Ann-Kristin Reyels's Jagdhunde (Hounds, Germany), an accomplished feature film debut, is set in snow-covered Uckermark just north of Berlin and stunningly lensed by cinematographer Florian Foest. Hounds comes across as a metaphorical statement on family disorientation in which losers try to pick up the pieces over the Christmas holidays. The film takes on emotional depth in the tender relationship between a deaf girl and a callow youth who has just moved into a farmhouse with his father, a dreamer with plans to turn the barn on his property into a wedding hotel!

Ulrike Ottinger's documentary Prater (Austria-Germany), a half-decade in the making, chronicles over the past century and more the attractions that contributed to the rise and fall of the world's oldest amusement park. Located in the centre of Vienna, and known to cineastes mostly because of the giant Ferris Wheel scenes in Carol Reed's The Third Man (UK, 1951), the Prater comes to life first with some quaint shots from the silent and early sound era, accompanied by interviews with eyewitnesses, then takes on a life of its own in the varied freak shows, dance contests, rollercoaster rides, parachute jumps, spook houses, tests of strength, and numerous other attractions. Prater is one of those films you want to see again.

Stefan Schwietert's Heimatklänge (Echoes of Home, Switzerland-Germany) is more a poem than a documentary. Schwietert assembles musicians and nonprofessionals from the Swiss and Austrian Alps who share a passion for singing. They yodel, warble, even hum from the top of the Alps, where the mountain valleys below serve as a kind of natural echo chamber. After becoming acquainted with the individuals who share this passion for Alpine singing, their voices enchant all the more as an exotic experience.

\section{Balkan Stories}

Srdjan Golubović's Klopka (The Trap, Serbia-Germany-Hungary) drew broad critical praise as one of the highlights in the Forum program. In this absorbing story of a good man who turns bad, an honest labourer agrees to a hitman contract in order to earn the money for an operation to save the life of his young son. The reasons for his acceptance are augmented by the misery of social conditions in Belgrade, affected by both gang wars and political corruption, thus allowing for an easy link to underworld forces. The Trap was scripted by the talented Srdjan Koljević, whose screenplays have helped significantly to maintain a quality standard in Serbian cinema.

Ognjen Svilicić's Armin (Croatia-Germany-Bosnia-Herzegovina), directed by the same Croatian filmmaker who had successfully presented his poignant family comedy Oprosti za Kung Fu (Sorry for Kung Fu, 2004) at the Forum two years ago, delighted his audience again with another quiet tongue-in-cheek tale cut from the everyday lives of little people in the Balkans. The fourteen-year-old Armin dreams of playing a role in the movies, so why not audition for a German film about the Bosnian war. But the trip with his father from their small town in Bosnia-Herzegovina by bus to Zagreb is apparently doomed when the bus breaks down en route. One mishap leads to another as the father valiantly tries to save his son's burgeoning career against odds that can only be imagined.

\section{Asian Dreams}


Two Japanese entries in the Forum were exceptional. In Kazuhiro Soda's amusing political documentary Senkyo (Campaign), shot in the tradition of "direct cinema" pioneered by American documentary filmmaker Robert Drew (Primary, 1960), follows the campaign route of a naive newcomer in the Liberal Democratic Party who wants badly to win a seat in the Tokyo City Council back in 2005. The candidate's campaign is plagued by his own stumbling efforts and unexpected humorous twists every step of the way. In the end, however, he does win his seat, although the vote count was a cliff-hanger through most of election night.

Ichijiku no kao (Faces of a Fig Tree), popular actress Momoi Kaori's first venture in the director's seat, explores the thin line between fantasy and reality. The setting is a small family house with a fig tree in the courtyard that fails to blossom and bear fruit. As the title hints, the motif of the fig tree reflects the destinies of the four family members. The father, who works a mysterious night job, dies on the construction site, and the mother later remarries. The daughter becomes pregnant from a man she hardly knows and bears a baby girl, to the delight of the new family circle. Meanwhile, some ants in an animation sequence comment on the goings-on with the same inquisitive questions that viewers might also raise. Faces of a Fig Tree shared the prestigious Netpac (Network for the Promotion of Asian Cinema) Prize.

The other half of the Netpac Prize in the Forum was awarded to Auraeus Solito's Tuli (Philippines), awarded Best Film and Best Director at the CineManila festival but still questionable as to whether it will be released uncut in the Philippines. Set in a rural village, where the traditional circumcision rite on young boys is unwillingly carried out by a young woman, the girl rebels by flaunting a lesbian relationship and opting to get pregnant by the only uncircumcised lad in the community. A poetic film with exotic-erotic nuances, Tuli comes across in the closing scene as a prolonged dream sequence.

\section{Kihachi Okamoto Retrospective}

The Forum played its trump card with a stunning 9-film retrospective honouring the late Kihachi Okamoto (1924-2005) in the presence of his producer wife Minako. Introduced last November with restored prints in a 12-film retrospective at the Filmex festival in Tokyo, the series embraces a wide range of styles and themes explored by a nonconformist director in the employ of the Toho Studio from the late 1950s to the late 1960s. Admittedly influenced by the cinema of John Ford and Howard Hawks, as well as the spaghetti Westerns of Leone and Carbucci, Okamoto fashioned his own version of the Samurai era in such mainstream hits as Daibosatsu toge (The Sword of Doom, 1966), Kiru (Kill, 1968), and Akage (Red Lion, 1969). Each of these films starred popular Samurai actors Toshiro Mifune and Tatsuya Nakadai in familiar roles but with ironic twists to set them apart from the contemporary Samurai films of Akira Kurosawa.

Just as important was Okamoto's indictment of the military in his war films: Dokuritsu gurentai (Desperado Outpost, 1959), Nihon no ichiban nagai hi (The Emperor and a General, 1967), and Nikudan (Human Bullet, 1968), the last named a low-budget venture produced by his wife and shot in $16 \mathrm{~mm}$. His films on political corruption, gang warfare, and social mores in postwar Japan - Ankokugai no taiketsu (The Last Gunfight, 1960), Jigoku no utage (Procurer of Hell, 1961), Edburiman shi no yuga na seikatsu (The Elegant Life of Mr. Everyman, 1963) - leave no doubt as to whose ethical rights he defended. As Forum programmer Christoph Terhechte noted in his introduction, the "Kihachi touch" stood for "originality, elegance, a wealth of ideas, and a lack of respect for cinematic convention." Deserving praise for a rediscovered Japanese master.

\section{City Girls}

Rainer Rother, the new head of the Berlin Film Museum, programmed "City Girls" as the cornerstone of the Berlinale Retrospective. The focus, of course, was on starlets of the silent screen. To wit: Clara Bow in Clarence Badger's It (1927), who graced the cover of the retrospective catalogue, Marion Davies in King Vidor's The Patsy (1928), Greta Garbo in Clarence Brown's Flesh and the Devil (1927), Louise Brooks in Frank Tuttle's Love 'Em and Leave 'Em (1926), and Gloria Swanson in Cecil B. DeMille's Why Change Your Wife? (1920).

The hit of the retro? Have you ever seen Asta Nielsen in the recently discovered and (two-strip) colourrestored Hamlet (Germany, 1921), co-directed by Svend Gade and Heinz Schall? The Danish prince is played by a Danish screen star - a rare instance in which Hamlet is interpreted by an actress. Modern music for the film has been composed for the premiere by Michael Riessler and performed by the Solisten-Ensemble. 


\section{References}

\section{AWARDS}

International Jury

Golden Bear

Tu ya de hun shi (Tuya's Marriage, China),

dir Wang Quan'an

Silver Bear, Grand Jury Prize

El otro (The Other, Argentina-France-Germany), dir Ariel Rotter

Silver Bear, Best Director

Joseph Cedar, Beaufort (Israel)

Silver Bear, Best Actress

Nina Hoss, Yella (Germany),

dir Christian Petzold

Silver Bear, Best Actor

Julio Chavez, El otro (The Other, Argentina-France-Germany),

dir Ariel Rotter

Silver Bear, Individual Artistic Contribution

Ensemble cast, The Good Shepherd (USA),

dir Robert De Niro

Silver Bear, Best Film Music

David Mackenzie, Hallam Foe (UK),

dir David Mackenzie

Alfred Bauer Prize, Film of Particular Innovation

Sai bo gu ji man gwen chan a (I'm A Cyborg, But That's OK, Republic of Korea), dir Park Chan-wook

First Feature Award Jury, Best First Feature Award

Generation 14 plus

Vanaja (India-USA), dir Rajnesh Domalpalli

International Short Film Jury

Competition

Golden Bear, Short Film

Raak (Contact), Netherlands),

dir Hanro Smitsman

Silver Bear, Short Film - ex aequo

Decroche (Pick-Up, France),

dir Manuel Schapira

Mei (Taiwan-USA),

dir Arvin Chen

Prix UIP Berlin

Rotten Apple (UK),

dir Ralitza Petrova

DAAD Short Film Award

Annem sinema ögreniyor (My Mother Learns Cinema, Turkey), dir Nesimi Yetik 
Independent Juries

FIPRESCI (International Critics) Jury

Competition

Obsluhoval jsem anglického krále (I Served the King of England, Czech Republic-Slovakia), dir Jiř́i Menzel

Panorama

Takva (Takva - A Man's Fear of God, Turkey-Germany),

dir Özer Kiziltan

Forum

Jagdhunde (Hounds, Germany), dir Ann-Kristin Reyels

Ecumenical Jury

Competition

Tu ya de hun shi (Tuya's Marriage, China),

dir Wang Quan'an

Panorama

Luo ye gui gen (Getting Home, Hongkong-China),

dir Zhang Yang

Forum

Chrigu (Switzerland),

dir Jan Gassmann, Christian Ziörjen

Prize of Guild of German Art House Cinemas

Competition

Hallam Foe (UK),

dir David Mackenzie

C.I.C.A.E. Jury (International Confederation of Art House Cinemas)

Panorama

The Bubble (Israel),

dir Eytan Fox

Forum

Heimatklänge (Echoes Of Home, Switzerland-Germany), dir Stefan Schwietert

Label Europa Cinemas

Panorama

El Camino de los Ingleses (Summer Rain, Spain-UK),

dir Antonio Banderas

Amnesty International Award

Panorama

När Mörkret Faller (When Darkness Falls, Sweden-Germany),

dir Anders Nilsson

Peace Film Award

Competition

Goodbye Bafana (Germany-France-Belgium-UK-Italy-South Africa), dir Bille August

NETPAC (Network for Promotion of Asian Cinema) Prize

Forum

Tuli (Philippines),

dir Auraeus Solito 
Ichijiku no kao (Faces of a Fig Tree, Japan),

dir Momoi Kaori

\section{Caligari Prize}

\section{Forum}

Kurz davor ist es passiert (It happened Just Before, Austria),

dir Anja Salomonowitz

\section{Special Mention}

Wolfsbergen (Netherlands-Belgium),

dir Nanouk Leopold

Dialogue en Perspective Award

Perspektive Deutsches Kino

Prinzessinnenbad (Pool of Princesses),

dir Bettina Blümner

\section{Special Mention}

Hotel Very Welcome, dir Sonja Heiss

\section{Femina Film Prize}

Bettina Böhler, for editing Yella (Germany),

dir Christian Petzold

\section{Panorama}

Panorama Short Film Award

Tes cheveaux noirs Ihsan (Your Dark Hair Ihsan, USA), dir Tala Hadid

\section{Special Mention}

Love This Time (Australia), dir Rhys Graham

\section{Prix UIP Berlin}

Rotten Apple (UK),

dir Ralitza Petrova

Panorama Audience Award

Blindsight (UK),

dir Lucy Walker

\section{Manfred Salzgeber Award}

The Tracey Fragments (Canada), dir Bruce McDonald

\section{Special Mention}

Boldog uj elet (Happy New Life, Hungary),

by Arpad Bogdan

\section{Teddy Awards}

Feature film

Ci-Qing (Spider Lilies, Taiwan),

dir Zero Chou

\section{Special Mention}

La León (Argentine-France), dir Santiago Otheguy

Documentary - Forum

A Walk Into The Sea: Danny Williams And The Warhol Factory (USA), dir Esther B. Robinson 
Special Teddy

Helmut Berger

Teddy Ballot Volkswagen Audience Award - Competition

Notes On A Scandal (USA-UK),

dir Richard Eyre

Generation Juries Prizes

Children's Jury Generation Kplus

Crystal Bear, Best Feature Film

Dek Hor (Dorm, Thailand),

dir Songyos Sugmakanan

Special Mention

Mukhsin (Malaysia), dir Yasmin Ahmad

Crystal Bear, Best Short Film

Menged (Ethiopia-Germany), dir Daniel Taye Workou

Special Mention

Land gewinnen (Gaining Ground, Germany), dir Marc Brummund

Generation 14plus Jury

Crystal Bear, Best Feature Film

Adama Meshuga'at (Sweet Mud, Israel-Germany-France-Japan),

dir Dror Shaul

Special Mention

The Fall (USA-UK-India),

dir Tarsem Singh

International Jury

Grand Prize, Best Feature Film

Mukhsin (Malaysia), dir Yasmin Ahmad

Special Prize, Best Short Film

Land gewinnen (Gaining Ground, Germany),

dir Marc Brummund

Special Mention

Drengen I kufferten (Having A Brother, Denmark),

dir Esben Toft Jacobsen

Tagesspiegel Readers Award - Forum

Heimatklänge (Echoes Of Home, Switzerland-Germany),

dir Stefan Schwietert

Berliner Morgenpost Readers Award - Competition

Irina Palm (Belgium-Germany-Luxembourg-UK-France),

dir Sam Garbarski

Siegessäule Readers Award - Panorama

The Bubble (Israel), dir Eytan Fox

Berlinale Talent Campus Award

Volkswagen Score Competition

Ilja Corić

Berlin Today Award

Wasserschlacht - The Great Border Battle, Kasia Klimkiewicz (Poland), Andrew Friedman (USA) 


\section{Berlinale Camera Awards}

Gianni Mina (Italy)

Márta Mészáros (Hungary)

Dorothea Moritz (Germany)

Ron Holloway (USA)

\section{Homages}

Arthur Penn

Kihachi Okamoto

Magnum in Motion

\section{Author Information}

Ron HOLLOWAY (1933-2009) was an American critic, film historian, filmmaker and correspondent who adopted Europe as his home in the early fifties and spent much of his life in Berlin. He was an expert on the study of German cinema and against all odds produced, with his wife Dorothea, the journal German Film, keeping us up-to-date with the work of directors, producers and writers and the showing of German films around the world.

In 2007, Ron Holloway and his wife were awarded the Berlinale Camera Award. Ron also received the Bundesverdienstkreuz (German Cross of Merit), Polish Rings, Cannes Gold Medaille, the American Cinema Foundation Award, the Diploma for Support of Russian Cinema and an honorary award from the German Film Critics' Association.

Ron was also a valued contributor to Kinema for the past fifteen years. 